\title{
Functional kinematics of the equine back
}

\author{
P. René van Weeren \\ Department of Equine Sciences, Faculty of Veterinary Medicine, Utrecht University, The Netherlands
}

\begin{abstract}
Summary
The back is the structure that links the four extremities and is central to the entire equine musculoskeletal system. From a gait analysis viewpoint the back has long been considered a rather rigid and static structure, but more recently the insight has gained ground that back dynamics are essential to equine performance. Motion patterns of thoracolumbar vertebrae are, however, characterised by small ranges of movements, which makes it difficult to measure back kinematics accurately. The facts that the motion patterns of the thoracolumbar vertebrae are intricately linked due to anatomical constraints and that the vertebrae are difficultly accessible make the technical problems wor$\mathrm{se}$, but in the last decade much progress has been made. Invasive experiments have permitted the development of computer programmes that enable the accurate assessment of spinal movement from non-invasive skin markers and the basic kinematic motion patterns in the live horse have been established. Recent research focuses at the relationship between lameness and back pain, on saddle-related items, and on the relationship of back motility and performance. In the latter category back motion studies are also used to answer the question whether certain equestrian activities can be considered harmful or not from a biomechanical viewpoint. It can be expected that the rapid technological developments will lead to an increase in (applied) research into back motion with a possible emphasis on the effects of riding and handling of horses. Indirect mathematical reconstruction of movement (modelling) based on easily obtainable input parameters may to some extent replace the often-cumbersome current direct measuring techniques.
\end{abstract}

Keywords: gait analysis, motion, kinematics, back, lameness, functional, performance

\section{Funktionelle Kinematic des Pferderückens}

Der Rücken verbindet die vier Gliedmaßen und stellt das Zentrum des gesamten muskuloskelettalen Systems dar. Vom Gesichtspunkt der Ganganalyse aus wurde der Rücken in der Vergangenheit als eher feste und statische Struktur betrachtet, neue Untersuchungen zeigen jedoch, dass die Rückendynamik für die Leistungsfähigkeit des Pferdes essentiell ist. Die Bewegungsmuster der thorakolumbalen Wirbel sind jedoch durch nur geringsgradige Motilität gekennzeichnet, was die exakte kinematische Vermessung des Rückens erschwert. Die Tatsachen, dass die Bewegungsmuster der Brust- und Lendenwirbel auf das Komplizierteste mit den anatomischen Bedingungen zusammenhängen und dass die Wirbel so schwer zugänglich sind, erschweren die technische Problematik. Doch in den letzten 10 Jahren konnten in der Forschung gute Fortschritte gemacht werden. Invasive Experimente erlaubten die Entwicklung von Computerprogrammen, welche die exakte Vermessung der Bewegung der Wirbelsäule über nicht invasive Hautmarkierungen zulassen. So war es möglich geworden, die grundlegenden Bewegungsmuster am lebenden Pferd zu ermitteln. Die neuesten Forschungen konzentrieren sich auf den Zusammenhang zwischen Rükkenbeweglichkeit und Lahmheit, auf Sattel-bezogene Fragestellungen und auf den Zusammenhang zwischen Rückenmotilität und Leistung. In Hinsicht auf Letzteres finden Rückenbewegungsstudien auch Anwendung für die Beantwortung der Frage, ob vom biomechanischen Standpunkt aus gewisse reiterliche Einwirkungen auf das Pferd als schädlich oder unschädlich anzusehen sind. Es ist zu erwarten, dass der rasante technische Fortschritt zu einer Intensivierung der angewandten Forschung auf dem Bereich der Rückenbewegung des Pferdes führen und dabei ein Schwerpunkt auf die Auswirkungen des Reitens und des Umgangs mit dem Pferd gelegt werden wird. Die indirekte mathematische Rekonstruktion (modelling) von Bewegung mit Hilfe leicht verfügbarer Inputparameter wird dabei die oft mühsamen direkten Messtechniken ersetzen können.

Schlüsselwörter: Ganganalyse, Bewegung, Leistung, Rücken, Kinematik, Lahmheit, Messung, funktionell

\section{Introduction}

In physics kinematics is defined as the branch of mechanics that is concerned with the motion of objects without taking into account the forces that generate that motion. The equine back has for a long time been considered as a very static structure and the notion that the motions of its constituting elements with respect to each other, tiny as those may be, have functional and, in pathological cases, clinical relevance has only recently gained ground.

In this paper first a short overview is given of the concepts that have dominated thinking about the functioning of the equine back from historical times up to the present day and then a a more detailed review is given of recent and ongoing research in the area. The paper concludes with a vision where to go from here. This latter part includes an attempt to identify interesting and/or much needed areas for research in the near future, making use of technical advances that may make things possible that were impossible before, and anticipating on expected changes in the perception and appreciation of equestrian activities by society at large.

\section{Historical perspective}

The first scientific observations on mammalian kinematics are attributed to Aristotle (384-322BC), who, in his treatise "De 
incessu animalium", described the footfall pattern of a walking quadruped. The first concept of how the back could possibly function comes from the famous Roman medical doctor of Greek origin Galen (131-201AD)(cited by Slijper 1946). Galen sees the back as a vaulted roof, sustained by pillars (the extremities). The spinous processes would prevent the roof from collapsing and for that reason the thoracic spinous processes have a dorsocaudal inclination, and the lumbar ones a dorsocranial. This basically static concept has held for centuries, as many concepts in the biomedical field that originated in Antiquity, but was recognised to be erroneous in the last part of the 18th or early 19th century. Main -and valid-argument to refute the theory was the fact that, if the idea were correct, the spinous processes would be constantly in contact, which they are not. In fact, if they are it gives rise to pathologic aberrations in the form of lysis and new formation of bone, mostly described as "kissing spines".

Galen's concept was, in an era when skills in civil engineering were developing rapidly and some until then unbelievable achievements were made, replaced by the "bridge" concept (Bergmann 1847, Zschokke 1895, Krüger 1939). In this, again static, concept the thoracolumbar vertebral column is seen as a bridge spanning the gap between two land abutments, i.e. the supports provided by the 4 limbs. In this concept the vertebral bodies were seen as the lower ledger of the bridge and the supraspinous ligament as the upper ledger. The spinous processes and the ligaments between them served as smaller girders, providing stability in craniocaudal direction. The concept held a long time and was further developed using various types of bridges to account for the effects of the head (and tail in certain species where the tail plays an important role in motion and in maintaining the equilibrium) (fig. 1). However, the concept contains a basic error because elastic structures such as the supraspinous ligament can only
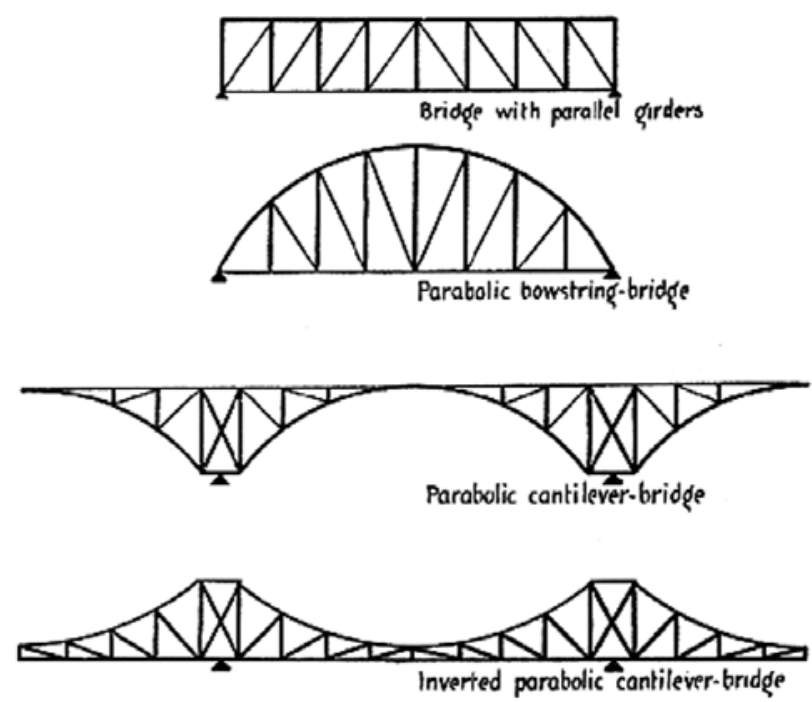

Fig 1 Various forms of bridges that have been used as a model for the mammalian back. (From: Slijper, E.J. (1946): Comparative biologic-anatomical investigations on the vertebral column and spinal musculature of mammals. Proc. K. Ned. Acad. Wetensch. 42, 1 128)

Unterschiedliche Brückenformen, die als Modell für den Rücken der Säugetriere Anwendung fanden resist tensile loads and no compressive loads. From a mechanical viewpoint the upper ledger of the bridge would be loaded under compression due to gravitational forces and the lower ledger under tension, just contrary to the way things were supposed to act.

The first concept that took into account the entire trunk and not only the thoracolumbar vertebral column with its soft tissue structures was the "bow-and-string" concept. The idea was first put forward by Barthez (1798), but remained largely unnoticed for a century and a half until it was picked up again by the zoologist Sliiper (1946). He compared meticulously in a large number of species the anatomy of the entire trunk in general and the morphology of the thoracolumbar vertebrae in particular. Based on these observations and the earlier work, he rejected the prevailing bridge concept and put forward the "bow-and-string" concept in which the mammalian trunk is seen as an ancient hand bow with the thoracolumbar vertebral column being the bow and the ventral musculature and linea alba the string (fig. 2). Just as is the case with a

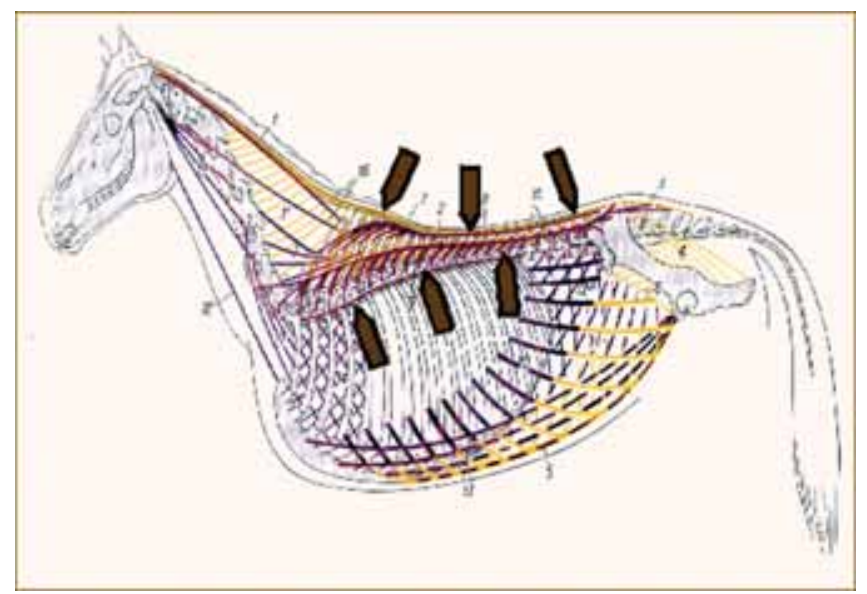

Fig 2 In the bow-and-string model the thoracolumbar vertebral column represents the bow and the muscles and ligamentous structures of the ventral midline the string. Tension side (supraspinous ligament, upper arrows) and compression side (vertebral bodies, lower arrows) are indicated. (Adapted from: Nickel et al. (1961). Lehrbuch der Anatomie der Haustiere. Band 1 Bewegungsapparat. 2. Auflage Paul Parey, Berlin).

Im Bogenmodell stellt die Brust-Lendenwirbelsäule den Bogen und die Muskeln und Bandstrukturen den ventralen Mittellinie.

hand bow, the system is under intrinsic tension and changes in one of the components will influence the other. Tensioning of the string will induce flexion (arching) of the bow, relaxation of the string will decrease flexion of the thoracolumbar vertebral column and active stretching of the latter, e.g. through contraction of the epaxial musculature, will elongate the string.

This concept of the mammalian back, that still prevails today, is the first dynamic model of back function and many factors can be identified that will influence the system. Gravitation always acts in a vertical downwards direction and the mass of abdominal contents will tend to extend the back (i.e. create a "hollow" back). The same, of course, applies to everything put on the back of a horse, including a rider. Contraction of the ventral musculature will tend to flex ("arch") the back, but, as mentioned earlier, the epaxial musculature will have an opposite effect because the work line of these muscles runs 
dorsal to the vertebral column. Only the psoas muscles, that are located ventral to the vertebrae, will have an opposite (flexing) effect. However, these muscles run only ventral to the last lumbar vertebrae and connect to the pelvis, so they will mainly affect the lumbosacral junction. The limbs are important determinants of back function too. Protraction of the front limbs will tend to extend the back, retraction results in flexion. The hind limbs have just an opposite effect. A last important factor is the head. Through traction on the withers via the large nuchal ligament lowering of the head should results in arching of the (cranial part of the) thoracolumbar spine, a higher position than normal will have the opposite effect. These effects are important for the assessment of some concepts of use of the horse (see later).

\section{Kinematics of the equine back}

The fact that it is now generally accepted that the equine back should be seen as a very dynamic entity, of which the movements are hence of vital importance, does not mean that these movements are large or easy to measure. In fact, studies on equine back movement have been extremely rare until rather recently due to the difficulties involved in measuring back movement.

The basic movements of the equine spine are ventro- and dorsiflexion (making a "hollow back", or "arching" the back), lateroflexion or lateral bending, and axial rotation. In movement science terminology this can be translated at the level of the individual vertebra into 3 rotations in an orthogonal coordinate system: one around the $X$-axis (flexion-extension), one around the Z-axis (lateroflexion), and one around the $Y$-axis (axial rotation).

In work done on anatomical specimens it was established that the lumbar part of the spinal column was very rigid, especially with respect to lateroflexion, with increasing mobility in cranial direction. The same applied to axial rotation (Townsend et al. 1983, Townsend and Leach 1984). This work was very valuable as it was the first research giving insight in the potential for movement of various parts of the equine spine, but it did obviously not represent reality, because data were not obtained in the living animal and there was therefore no influence of any of the active structures.

The first attempts in the living animal to determine back motion were non-invasive (Licka and Peham 1998, Pourcelot et al. 1998, Audigié et al. 1999). Licka et al. (2001) developed a practical non-invasive method that was based on the measurement of both lateral and dorsoventral excursions of skin markers expressed as a percentage of height at the withers. Such techniques serve well for comparing horses under different conditions, but are not representative for the motion patterns of the underlying bony structures. In fact, it soon became clear that the complex and coupled movements of the vertebrae could never be adequately studied using surface markers. For instance, lateroflexion will always be accompanied by axial rotation and vice versa (fig. 3). This complex movement is not deducible from the change in position of a skin marker. In a collaborative effort of the Utrecht and Uppsala Equine Biomechanics Research Groups a large invasive experiment was carried using Steinmann pins implanted in the spinous processes of a number of vertebrae. This set-up enabled the direct measurement of vertebral movement. Data were acquired at walk (Faber et al. 2000), trot (Faber et al. 2001a) and canter (Faber et al. 2001b). Using these data computer programs were developed that could predict reliably real spinal kinematics from kinematic data obtained using skin markers (Faber et al. 2001c). The technique appeared to be highly reproducible, also when used in different lab settings (Faber et al. 2002).

From this research it turned out that spinal motion was by far less at trot than in the other two gaits. This reflects that the back is held stiffer in this very symmetrical gait in which the movements of the contralateral front and hind limbs are tightly coupled. At the walk, the range of motion for flexion-extension is fairly constant for vertebrae caudal to Th 10 (approximately $7^{\circ}$ ), lateral bending is most evident in the cranial thoracic vertebrae and in the pelvic segments (values up to 5.6\%), but less in the lumbar region between Th 17 and L5, which is relatively stiff $\left(<4^{\circ}\right)$. Axial rotation increases gradually from

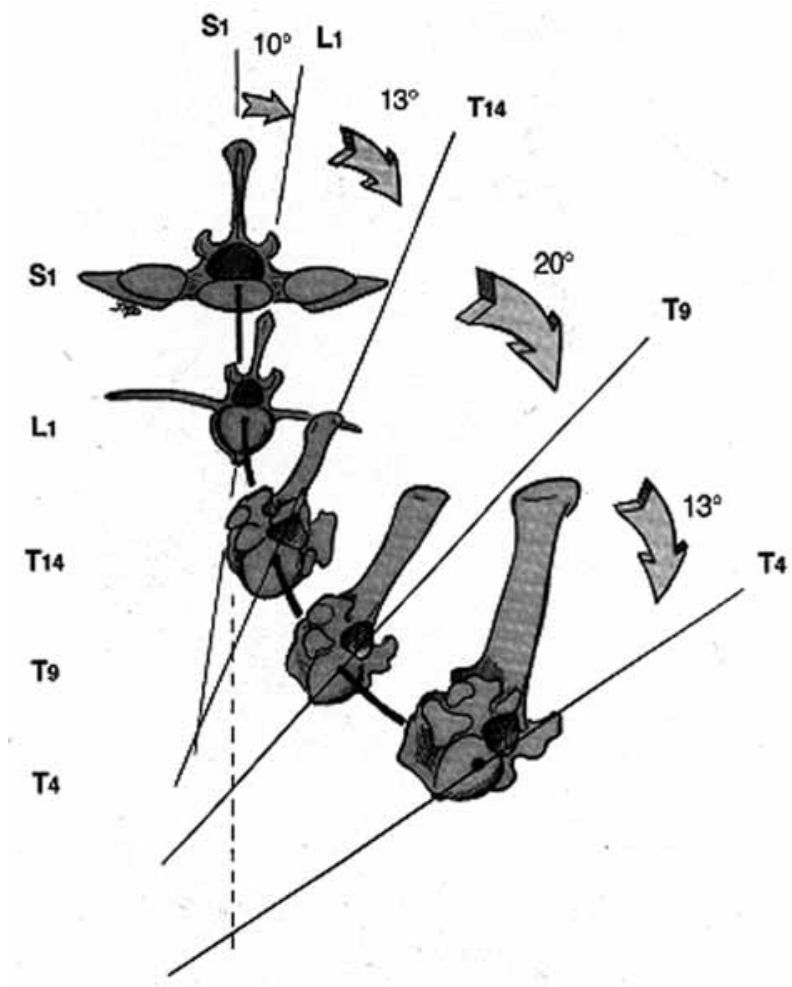

Fig 3 Lateroflexion of the thoracolumbar spine is always coupled with axial rotation.

Die Lateralbeugung der Brust-Lendenwirbelsäule ist immer mit axialer Rotation verbunden.

$4^{\circ}$ at Th 6 to $13^{\circ}$ at the tuber coxae. At the trot the range for flexion-extension for all vertebrae does not exceed 2.8-4.9 , and lateral bending is less $\left(1.9-3.6^{\circ}\right)$. Axial rotation at trot is about $3^{\circ}$. At the canter flexion-extension movement is substantially larger than in all other gaits (maximal range $15.8 \pm 1.3^{\circ}$ ). Lateral bending is maximally $5.2 \pm 0.7^{\circ}$ and axial rotation $7.8 \pm 1.2^{\circ}$.

From a viewpoint of clinical research, variability is an important item. Variability within the same horse is relatively limited for flexion-extension and axial rotation (6-8\%), but more for 
lateroflexion (8-18\%). The between-horse variability between horses is obviously larger, here too lateroflexion shows most variation (16-25\%), which is substantially more than the comparable amount of variation in the rotation around the other two axes (10-16\%).

\section{Recent developments}

Interest in function and dysfunction of the equine back has been growing rapidly from the second half of the 1990s onwards, resulting in an increasing number of publications on the topic. The increase in scientific output is driven by the growing awareness of the importance of the back for equine locomotion and performance, being the connecting element of the limbs, and has been made possible by the rapid technological developments, including an enormous increase in computational capacity, in recent years. The work that has been done and is currently being carried out comprises various areas of back physiology and pathology, covering topics ranging from in vitro work and the development of field techniques to the creation of mathematical models of the equine spine.

\section{In vitro research}

Acknowledging the role of anatomical constraints as the basis for all motions of the equine back, Degeverce et al. (2004) have continued the line of in vitro research initiated by Townsend et al. (1983), and further pursued by Denoix (1987, 1992, 1999), in studying the motion of the sacro-iliac joint (SIJ) in anatomical specimens. The SIJ is well known to play an important role in human lower back pain (Pool-Goudzwaard et al. 2003), but in the horse, although the SIJ is often incriminated as a cause for back pain, even its range of motion had never been established. It resulted that there is only a very limited amount (on average less than one degree) of nutation (which is the rotation of the pelvis in relation to the sacrum around the $X$-axis, i.e. the axis perpendicular to the sagittal plane), related to the much larger dorsal-ventral flexion motion (approximately $24^{\circ}$ ) of the lumbosacral joint (LSJ). When the sacrosciatic and sacrotuberal ligaments are severed, this range of motion almost doubles. It is concluded that SIJ motion is much less than expected based on earlier work (Faber et al. 1999), probably because of a different analysis technique, and that these small amounts of motion most probably are too small to be measured in vivo.

\section{The relationship of back problems with lameness}

Back problems are in the clinical setting often related to poor performance and sub-clinical lameness, especially of the hind limbs. Although there is common agreement that there is a mutual influence of lameness on back function and vice versa, the extent of this relationship and the mechanistic aspects of it are far from clear. In a recent survey a group of orthopaedic patients and a control group of animals presented for a pre-purchase exam (as the most appropriate control population) were subjected to a full lameness examination as well as a full back examination, irrespective of their eventual complaints. In that study, which was one of the first field studies on the subject, it appeared that the prevalence of lameness in horses with a diagnosed back problem was much higher than in horses without such a problem. Of 805 horses presented as suspected of an orthopaedic ailment, in 208 (26\%) there were indications for both lameness and back pain (Landman et al., 2004). These figures do not give, however, evidence about a causal relationship. In another recent study Dyson (2005) diagnosed concurrent forelimb and or hind limb lameness due to an unrelated cause in $46 \%$ of a series of horses with primary thoracolumbar or sacroiliac region pain. Causal relationships between lameness and back movements can only be demonstrated in experimental studies. It has been shown that experimentally induced forelimb or hind limb lameness may alter the biomechanics of the equine back (Buchner et al. 1996, Pourcelot et al. 1998). Very recently it has been established, however, that when very subtle lameness is induced (maximally 2/5), the influence on back motion is very limited (Gómez Alvarez et al., in preparation). This makes sub-clinical lameness as a cause for back pain improbable. It should be stated though that all these studies have investigated the acute effect of induced lameness on back motion whereas in the clinical setting it can be presumed that long-term effects of chronic lameness are more important.

Few studies so far have focused on the effect of induced back pain. Jeffcott et al. (1982) induced reversible back pain in Standardbred trotters by the injection of a high concentration of lactic acid in the epaxial musculature. They did not see effects on linear and temporal stride parameters (stride length, stride frequency, pro- and retraction angles). In a very recent study in Dutch Warmbloods, in which the same technique to induce back pain was used, this observation could be confirmed (Wennerstrand et al., in preparation), but in a study on patients suffering from back pain as diagnosed by repeated palpation a shorter stride length at walk (not at trot) was found in the back pain patients compared to healthy controls (Wennerstrand et al. 2004). In both studies a significant influence of back pain on spinal kinematics could be noted.

\section{Saddle pressure}

The role of the saddle in riding has been a concern for ages, and (weighted) saddles are known to influence back motion (DeCocq et al. 2004) (fig.4). The introduction on the market of devices that can be used to measure the pressure under the saddle has received considerable attention as this technique was considered to be very helpful in quantifying the very difficult and so far highly subjective area of assessing saddle fit and in studying the relationship of rider and horse (Harman $1994,1997)$. Potentially promising, the technique is still in its infancy in which the potential possibilities of the technique are explored (Werner et al. 2002) and normal pressure patterns established (Fruehwirth et al. 2004). Although the first report (in the square standing horse!) on the validity of this kind of systems was encouraging (Jeffcott et al. 1999), it has become clear that the systems may not be as reliable as hoped for (DeCocq et al. 2005). The practical application of these systems in moving and athletically performing horses is fraught with piffalls due to insufficient fit of the pad to the shape of the equine back, wrinkling of the pad, shear forces that are unaccounted for but interfere with outcome, size of load 
cells, maximal measuring capacity of load cells, and other technical factors. There is little doubt that these technical problems will be overcome in the future, but at present the systems cannot be considered to give unequivocal and relia-

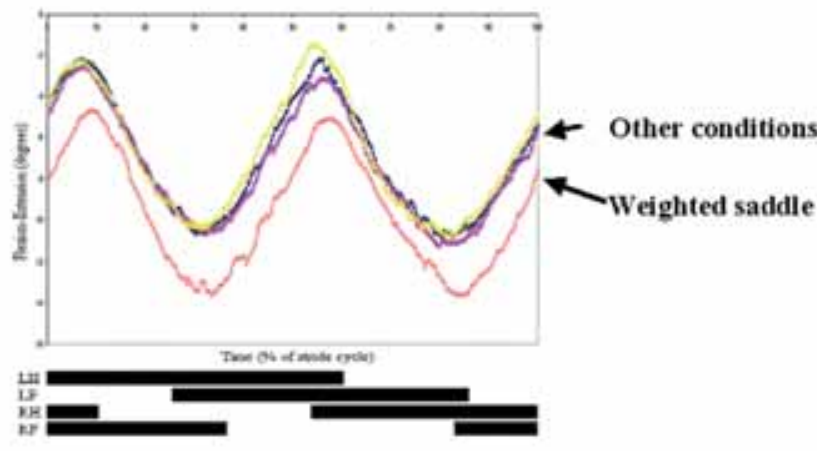

Fig 4 Range of motion during a single stride cycle of T13 in 4 conditions: without a saddle, with only a tightened girth, with saddle and tightened girth, and with loaded saddle $(75 \mathrm{~kg})$ and tightened girth. Only the last condition differs significantly and results in an overall increase in extension. However, range of motion (maximal flexion minus maximal extension) remains the same.

Bewegungsbereich von 113 während eines einzelnen Schrittzyklus unter 4 Bedingungen: ohne Sattel, mit schwach angezogenem Gurt, mit Sattel und angezogenem Gurt sowie mit belastetem Sattel (75kg) und angezogenem Gurt. Nur die letzte Bedingung unterscheidet sich significant und führt zu einer allgemeinen Erhöhung der Extension. Der Gesamtbewegungsbereich (maximale Flexion minus maximale Extension) bleibt jedoch gleich.

ble results. A possible approach to come to better results was recently shown in a paper by Meschan et al. (2006), who measured at selected areas under the saddle and who limited their work to intra-individual comparisons.

\section{The back and performance}

The empirically established relationship between conformation (and visually assessed gait, or kinematics in other terms) and performance has formed the basis for the selection of breeding stock ever since man began to purposefully breed horses after domestication (Holmström 2001). Recently, back kinematics has received special attention in relationship to jumping performance. Cassiat et al. (2004) were able to show significant differences in back kinematics between two groups of show jumpers performing at a high and a low level respectively. The good performers appeared to pitch their back line less forward during the forelimb stance phase before take-off and to straighten it more after landing, probably indicating a more efficient strutting action of the forelimbs. Bobbert et al. (2005) reported a different back action between the best and worst performers in a puissance competition. At hind limb clearance, the best jumpers had their centre of gravity further beyond the fence. This was possible because the best jumpers had a greater angle between the trunk and the hind limbs. This greater angle, in turn, was partly attributed to increased flexion in the knee joints, but partly also to a 0.1 rad further tilting of the sacrum. The observations in these studies lend support to the current practice of having visual inspections of submaximal free jumps at foal age in the process of selection of talented show jumpers. A completely different relationship of back kinematics to performance is the effect of specific forms of equestrian activity on the back. In dressage, horses are required to compete in certain positions that do not correspond to the natural position that the horse would assume of its own free will. This is especially obvious with respect to the position of the head and neck, which is described in the rules of the Fédération Equestre Internationale (FEI) as: "The neck should be raised, the poll high and the head slightly in front of the vertical", implying a much more upright position than in the natural situation. Guidelines for the correct position of the head and neck in dressage have been given and discussed for ages in the equestrian literature (Cavendysh 1674, de Solleysel 1733, Lenoble du Teil 1889, Decarpentry 1971), but still continue to be a source of controversy at present times (Balkenhol et al. 2003, Janssen 2003). In this discussion the acceptability from an animal welfare viewpoint of certain training techniques implying head/neck positions strongly diverging from the natural position take a prominent position. In a recent comprehensive study carried out by an international consortium that included kinematic and kinetic parameters and saddle pressure data on the effects of head and neck position, it could be established that there was a significant influence of head/neck position on thoracolumbar kinematics, above all in the sagittal plane. Positions with an elevated neck tended to induce extension in the thoracic region and flexion in the lumbar region. Lower neck positions produced the opposite. High neck positions generally led to a restriction of range of motion (ROM) of vertebrae, especially in the lumbar area, but low-neck positions increased ROM (fig. 5). A

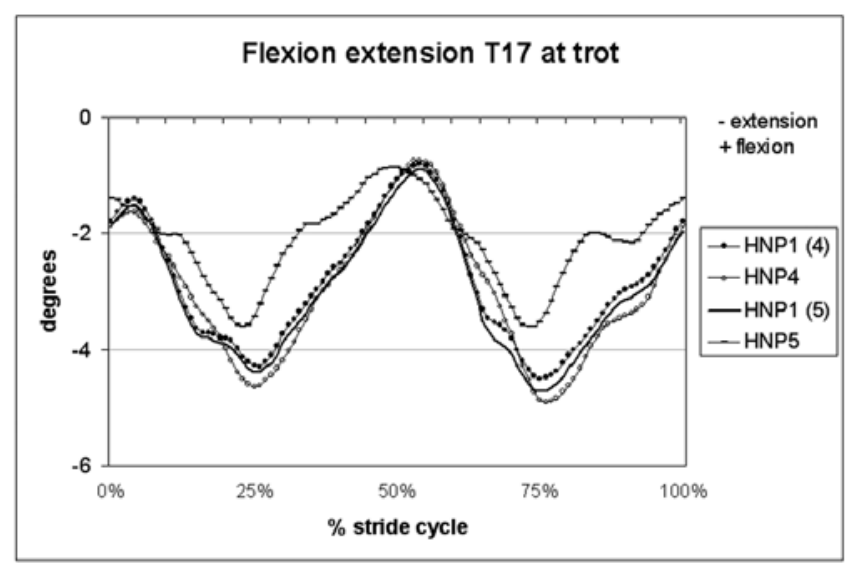

Fig 5 Mean flexion/extension angular motion pattern of one horse (T17 at trot): The curves represent the two most extreme head positions and their controls (HNP1 = natural position). HNP4: neck lowered and flexed, bridge of the nose considerably behind the vertical; HNP5: neck extremely elevated and bridge of the nose considerably in front of the vertical. At T17, the low position (HNP4) increases the range of motion only slightly (a larger effect is seen in the more cranially located vertebrae), in contrast, the high position (HNP5) strongly distorts the normal motion pattern.

Mittleres Flexions-/Extensionswinkel-Bewegungsmuster eines einzelnen Pferdes (T17 im Trab): Die Kurven zeigen die beiden extremsten Kopfhaltungen und deren Kontrollen (HNPT=natürlich Position). HNP4: Genick gesenkt und gebeugt, Nasenrücken deutlich hinter der Vertikalen; HNP5: Genick extrem gehoben, Nasenrücken deutlich vor der Vertrikalen. An 117 erhöht die niedrige Position (HNP4) den Bewegungsbereich nur leicht (ein größerer Effekt zeigt sich bei den mehr kranial gelegenen Wirbeln). Im Gegensatz dazu verändert die hohe Position (HNP5) das normale Bewegungsmuster hochgradig.

very high position of the neck seemed to greatly disturb normal kinematics, much more than a strongly flexed position (Gómez Álvarez et al., accepted). These results confirmed 
earlier work concerning a more restricted number of head and neck positions (Rhodin et al. 2005). It is anticipated that more work will be done in this important area, the outcome of which may influence the policy of sport-regulating bodies such as the FEI as well as, and interrelated with this, public opinion about the ethical acceptability of certain equestrian activities (van Weeren 2005). The importance of the issue was underlined by the recent (2006) workshop organized by the FEl at their Lausanne headquarters in which the acceptability of the "Rollkür" or "over bended" training technique, in which the horse is ridden with a strongly flexed mid-cervical region that brings the head almost down between the front limbs, was discussed. The preliminary outcome was that "there was clearly no evidence at the present time that any structural damage is caused by this training exercise, when used appropriately by expert riders" (Jeffcott 2006).

\section{Mathematical modelling}

The relative ease with which quantitative data can be collected and the enormous increase in computational capacity since the large-scale introduction of computers about two decades ago, allow for the development of complicated mathematical models of biological structures and their function. Modelling on the basis of finite element analysis is commonplace in engineering, but is more complicated in living tissues, which almost always consist of heterogeneous materials that in some cases may undergo morphological changes due to voluntary movements. Realistic modelling is only possible if input parameters, among which material properties, are correct. Currently, studies are undertaken to determine material properties, such as stiffness, of the equine back (Schlacher et al. 2004). These, and other input parameters can serve as a basis for the modelling of the effects of certain events, for example a rider, on the back (Peham and Schobesberger 2004). Though far from perfect at present, models of the equine back may increase in importance in the future, as their accuracy grows, to evaluate and predict the effects of certain interventions on the function of the equine back.

\section{Conclusion}

It can be concluded that the equine back is a very complex structure that takes a central position in the entire equine musculoskeletal system and hence can be decisive for performance. A good knowledge of how the back functions, is therefore essential. The close interrelationship between the limbs and the back (and neck) is often underestimated and not yet fully understood. The biomechanical concept of the action of the back is crucial too for a good understanding of various riding techniques in dressage horses and how certain training methods could affect the musculoskeletal system. It should be emphasised, however, that this matter is extremely complex, as there are many factors that may influence performance. Of these, the character of the equestrian activity itself, the quality of the rider and the tack are among the most important.

In recent years, much progress in the understanding of the functioning of the equine back has been made using a variety of technical approaches. It can be anticipated that, notwithstanding the limitations all kinematic gait analysis systems suffer (van Weeren 2002), computerised analysis of spinal kinematics will become more popular as an aid in diagnosis and to monitor recovery and/or the success of chosen therapies.

Areas of interest for future research include the complex interaction between rider and horse, both biomechanically through the weight of the rider (with in most cases a saddle as interface) and more technically through the effect of reins and spurs. It can be expected that technical progress will enable the development of sensitive and reliable instrumentation techniques to measure these influences. One can, for instance, think of saddles with inbuilt pressure measuring devices that can record and store data during a wide variety of equestrian activities, which data could then be retrieved through a simple USB-portal in the saddle. Telemetric transference of real-time data would be another option. Such a technique would overcome most of the problems encountered with the actual saddle mats. Similar technology could be developed for the instrumentation of reins, spurs, or any other type of tack. On the horse side, it can be foreseen that the rapid development of modelling and animation techniques, which is for a large part driven by the entertainment industry, may to a large extent replace the often-cumbersome direct measuring techniques used today.

The equine research community will need these technological advances to provide answers to questions raised by society at large. Society is becoming more critical with respect to the use of animals for human benefit and some practices in the equine industry are not undisputed. The recent upheaval about the ethical acceptability of certain training techniques ("Rollkur" "over bending" or "hyperflexion") shows how easily popular concern can be provoked. In fact, there are other practices in equine sports that could be classified as more questionable than this specific item, and the equine industry would do itself a favour doing good research about the effect of equestrian activities on the health and well-being of the horses in order to have the answer ready once the inevitable questions come.

\section{References}

Aristotle (1961): Parts of animals; movements of animals; progression of animals. (eds: A. L. Peck and E. S. Forster). The Loeb Classical Library. London, Heinemann

Audigié F., Pourcelot P., Degeurce C., Denoix J. M. and Geiger D. (1999): Kinematics of the equine back: flexion-extension movements in sound trotting horses. Equine vet. J. Suppl. 30, 210-213

Balkenhol K., Müller H., Plewa M. and Heuschmann G. (2003): Zur Entfaltung kommen - statt zur Brust genommen. Reiter Revue 46, $46-51$

Barthez P. J. (1798): Nouvelle mécanique des mouvements de I'homme et des animaux. Paris.

Bergmann C. (1847): Über die Verhältnisse der Wärme-Ökonomie der Thiere zu ihrer Grösse. Göttinger Studien, Abt. 1.

Bobbert M. F., Santamaría S, van Weeren P. R., Back W. and Barneveld A. (2005): Can jumping capacity of adult show jumping horses be predicted on the basis of submaximal free jumps at foal age? A longitudinal study. Vet. J. 170, 212-221

Buchner H., Savelberg H., Schamhardt H. and Barneveld A. (1996): head and trunk movement adaptations in horses with experimentally induced fore- or hind limb lameness. Equine vet. J. 28, 71-76

Cavendysh G. (1674): Méthode nouvelle et invention extraordinaire de dresser les chevaux et les travailler selon la nature. Londres, Tho. Milbourne 
Cassiat G., Pourcelot P., Tavernier L., Geiger D., Denoix J. M. and Deguerce C. (2004): Influence of individual competition level on back kinematics of horses jumping a vertical fence. Equine vet. J. 36, 748-753

Decarpentry A. (1971): Academic Equitation. (Translated from the 2nd revised ed. of Equitation Académique). London, J.A. Allen \& Co. Ltd

DeCocq P., van Weeren P. R. and Back W. (2004): Effects of girth, saddle and weight on movements of the horse. Equine vet. J. 36, 758-763

DeCocq P., van Weeren P. R. and Back W. (2005): Saddle pressure measuring: Validity, reliability and power to discriminate between different saddle-fits. Vet. J., in press, available on line (www.siencedirect.com).

Degueurce C., Chateau H. and Denoix J. M. (2004): In vitro assessment of the sacroiliac joint in the horse. Equine vet. J. 36, 694-698

Denoix J. M. (1987): Kinematics of the thoracolumbar spine in the horse during dorsoventral movements: a preliminary report. In: Proc. 2nd Intern. Conf. Equine Exerc. Physiol. Eds: Gillespie, J.R. and Robinson, N.E.. ICEEP Publications, Davis (CA), pp 607-614

Denoix J. M. (1992): Aspects fonctionnels des régions lombo-sacrale et sacro-iliaque du cheval. Pract. vet. Equine 24, 13-21

Denoix J. M. (1999): Ultrasonographic evaluation of back lesions. Vet. Clin. North Am. Equine Pract. 15, 131-159

De Solleysel J. (1733): Le parfait maréschal, qui enseigne à connoistre la beauté, la bonté et les défauts des chevaux. Paris, PierreJean Mariette

Dyson S. (2005): The interrelationships between back pain and lameness: a diagnostic challenge. Proc. Congr. Brit. Equine Vet. Assoc. 44, 137-138

Faber M., Schamhardt H. C. and van Weeren P. R. (1999): Determination of $3 \mathrm{D}$ spinal kinematics without defining a local vertebral co-ordinate system. J. Biomech. 32, 1355-1358

Faber M. J., Schamhardt H. C., van Weeren P. R., Johnston C., Roepstorff L. and Barneveld A. (2000): Basic three-dimensional kinematics of the vertebral column of horses walking on a treadmill. Am. J. Vet. Res. 61, 399-406

Faber M. J., Johnston C., Schamhardt H. C., van Weeren P.R ., Roepstorff L. and Barneveld A. (2001a): Basic three-dimensional kinematics of the vertebral column of horses trotting on a treadmill. Am. J. Vet. Res. 62, 757-764

Faber M. J., Johnston C., Schamhardt H. C., van Weeren PR., Roepstorff L. and Barneveld A. (2001 b): Three-dimensional kinematics of the equine spine during canter. Equine vet. J. Suppl. 33, 145-149

Faber M. J., Schamhardt H. C., van Weeren P. R. and Barneveld A. (2001c): Methodology and validity of assessing kinematics of the thoracolumbar vertebral column in horses based on skin-fixated markers. Am. J. Vet. Res. 62, 301-306

Faber M. J., Johnston C., van Weeren P. R. and Barneveld A. (2002): Repeatability of back kinematics in horses during treadmill locomotion. Equine vet. J. 34, 235-241

Fruehwirth B., Peham C., Scheidl M. and Schoesberger H. (2004): Evaluation of pressure distribution under an English saddle at walk, trot and canter. Equine vet. J. 36, 754-757

Gómez Álvarez C. B., Rhodin M., Bobbert M. F., Weishaupt M., Johnston C. and van Weeren P. R. (2006) The effect of different head and neck positions on the thoracolumbar kinematics in the unridden horse. Equine vet. J. Suppl. (ICEEP 2006), accepted for publication.

Harman J. C. (1994): Practical use of a computerized saddle pressure measuring device to determine the effects of saddle pads on the horse's back. J. Equine Vet. Sci. 14, 606-611

Harman J. C. (1997): Measurements of the pressures exerted by saddles on the horse's back using a computerized pressure measuring device. Pferdeheilkunde 13, 129-134

Holmström M. (2001): The effects of conformation. In: Equine Locomotion. Eds: W. Back and H. M. Clayton. London: W.B. Saunders.

Janssen S. (2003): Zur Brust genommen. Reiter Revue 46, 41-45

Jeffcott L. B. (ed.) (2006): Report of the FEI Veterinary and Dressage Committees' Workshop - The use of over bending ("Rollkur") in FEl Competition. FEl Internal publication. FEl, Lausanne

Jeffcott L. B., Holmes M. A. and Townsend H. G. G. (1999): Validity of saddle pressure measurements using force-sensing array technology - preliminary studies. Vet. J. 158, 113-119
Jeffcott L. B., Dalin G., Drevemo S., Fredricson I., Björne K. and Bergquist A. (1982): Effect of induced back pain on gait and performance of trotting horses. Equine Vet. J. 14, 129-133

Krüger W. (1939): Über Schwingungen der Wirbelsäule -insbesondere der Wirbelbrücke- des Pferdes während der Bewegung. Berl. Münchn. Tierärzłl. Wschr. 13, 129-133

Landman M. A. A. M., de Blaauw J. A., van Weeren P. R. and Hofland J. J. (2004): Lameness prevalence in horses with back problems compared to a control population: a field study. Vet. Rec. $155,165-168$

Licka T. and Peham C. (1998): An objective method for evaluating the flexibility of the back of standing horses. Equine vet. J. 30, 412-415

Licka T., Peham C. and Zohmann E. (2001): Range of back movement at trot in horses without back pain. Equine vet. J. Suppl. 33, 150-153.

Lenoble de Teil J. (1889): Cours théorique d'équitation, de dressage et d'attelage. Paris, Berger-Levrault.

Meschan E. M., Peham C., Schobesberger H. and Licka T. F. (2006): The influence of the width of the saddle tree on the forces and the pressure distribution under the saddle. Vet. J., accepted February 1st, 2006, available online at www.sciencedirect.com.

Peham C. and Schobesberger H. (2004): Influence of the load of a rider or of a region with increased stiffness on the equine back: a modelling study. Equine vet. J. 37, 703-705

Pool-Goudzwaard A., Hoek van Dijke G., Mulder P., Spoor C., Snijders C. and Stoeckart R. (2003): The iliolumbar ligament: its influence on stability of the sacroiliac joint. Clin. Biomech. 18, 99-105

Pourcelot P., Audigié F., Degueurce C., Denoix J. M. and Geiger D. (1998): Kinematics of the equine back: a method to study the thoracolumber flexion-extension movements at the trot. Vet. Res. 29, 519-525

Rhodin M., Johnston C., Holm K. R., Wennerstrand J. and Drevemo S. (2005): The influence of head and neck position on kinematics of the back in riding horses at the walk and trot. Equine vet. J. 37, 7-1 1

Schlacher C., Peham C., Licka T. and Schobesberger H. (2004): Determination of the stiffness of the equine spine. Equine vet. J. 37, 699-702

Sliiper E. J. (1946): Comparative biologic-anatomical investigations on the vertebral column and spinal musculature of mammals. Proc. K. Ned. Acad. Wetensch. 42, 1-128

Townsend H. G., Leach D. and Fretz P. B. (1983): Kinematics of the equine thoracolumbar spine. Equine vet. J. 15, 117-122

Townsend H. G. and Leach D. (1984): Relationship between intervertebral joint morphology and mobility in the equine thoracolumbar spine. Equine vet. J. 16, 461-465

Van Weeren P. R. (2002): The clinical applicability of automated gait analysis systems. Equine vet. J. 34, 218-219

Van Weeren P. R. (2005): Equine ergonomics: a new era? Equine vet. J. 37, 4-6

Wennerstrand J., Johnston C., Roethlisberger-Holm K., Erichsen C., Eksell P. and Drevemo S. (2004): Kinematic evaluation of the back in the sport horse with back pain. Equine vet. J. 36, 707-711

Werner D., Nyikos S., Kalpen A., Geuder M., Haas C., Vontobel H. D., Auer J. A. and von Rechenberg B. (2002): Druckmessungen unter dem Sattel: eine Studie mit einem elektronischen SattelMesssystem (Novel GmbH). Pferdeheilkunde 18, 125-140

Zschokke E. (1892): Untersuchungen über das Verhältnis der Knochenbildung zur Statik und Mechanik des Vertebraten-skelettes. Thesis, ZürichLegends for illustrations

P. R. van Weeren DVM PhD Dipl ECVS,

Department of Equine Sciences,

Faculty of Veterinary Medicine,

Utrecht University

Yalelaan 12

NL-3584 CM Utrecht,

The Netherlands

r.vanweeren@vet.uu.nl 